\title{
Women Participation In Agricutural Decision-Making In Aguata Local Governmmment Area, Anambra State
}

\author{
Okafor .C. N
}

Agricutural Engineering Department

Federal Polytechnic, Oko, Anambra State

Nigeria

\begin{abstract}
A study involving 120 women respondents investigated the level of women farmer's participation in Agricultural decision-making in Aguata Local Government Area (LGA) of Anambra State. Primary data were collected using structured questionnaire and interview schedule. The data were analyzed using descriptive statistics. Results showed that majority of the women farmers (80\%) had between 10 to 20 years farming experience which helped them in making rational choice and decisions. About $75 \%$ of the women were full-time farmers who have contact with extension agents and belonged to Cooperative Societies. Results also showed that there was a low level (100\%) of women farmers' participation in taking major decision in group agricultural projects involving men. However $60 \%$ are involved in crucial farm decisions at family level. It is recommended that involving women farmers in decision-making at all stages of group and family agricultural projects should be a policy in the $L G A$ and a road map to achieving sustainable agricultural development. Policy makers and planners therefore, need to acknowledge that farmers and other groups in the agricultural production chain can only work effectively within the framework of the policies that they put in place.
\end{abstract}

\section{INTRODUCTION}

Women across the developing world are disadvantaged relative to men. Under maledominated social structure and political system, women are denied equal access to land structure and extension services (Okafor et al 2002). The failure to consults women or to consider their specific capabilities and responsibilities can prevent new agricultural projects or technologies from adopted. Tradition and customs in different regions and communities make men believe that women should be used rather than loved, worked rather than be cared for, seen rather than be heard and as result women have no voice, no right and little chance to improve their situation especially where women farmer (Awake, 1998). The extent to which a farmer is able to perform the various agricultural tasks depends on the level of knowledge and skill possessed by the individual. It has been demonstrated in agricultural extension that many innovations are not adopted by farmers because they are based on wrong assumption about the women farmers, whose real needs are not actually met or served (lloka, 2002).

Attention has been drawn to the fact that women do not participate in policy formulation and decision-making process, even in the issues that affect them directly (Mbilinyi, 1990, UNICEF, 1985). Attempts to include women farmers in decisionmaking bodies and their participation in minimal (Baaakri and Besha, 1989). 
It is argued that women tend to be quiet in meetings especially public meetings. The women voice is rare in meeting despite their presence (UWT, 1982). Many reasons explained this stage that women merit special attention as a 'group' apart from others and by cultural rules prohibiting their presence (e.g. Moslem women) or active participation in some context (e.g. certain kinds of formal meetings or rituals) or by their restricted economic means (e.g. very few rural women farmers can afford radio or television of their own). Women have been conditioned by socio-cultural structures not to be heard/vocal in public especially in the presence of men (husbands) even when they have good ideas (Davies and Graves, 1985). Female farmers are often the voiceless particularly when it comes to influencing agricultural policies and projects. In 1988, women in Agricultural (WIA) programmes were formed in an attempt to address the genders related deficiencies with the existing extension programme. Up till this point, the ADP projects had contained only a home economic wing responsible for home-related activities. This was also revealed by David (2006).

Karunmi and Ezumah (1989) state that any policy instrument aimed at improving agricultural production in Nigeria must recognize the place of women in the process. They emphasize the need for their active participation in agricultural decision-making to enable the women explain and expand their productive base.

Recently, development agencies in particular, are taking special cognizance of the prudence of including women in every development project. The United States Agency for International Development (USAID) also holds a similar conviction that "to pursue a development policy without women in development focus would be wasteful and self defeating" (Osuala, 1991). A study finances by the united Nations Development Programme (UNDP) confirmed that women make up 60 to 80 percent of the agricultural labour force in Nigeria depending on the region, and produce two-third of the food crops. Despite these facts, widespread assumption that men and not women make the key farm management decisions has prevailed. The urgent need to include women adequately in rural extension decision-making activities as a policy, formed the central focus of this study.

\section{METHODOLOGY}

The study was conducted in Aguata Local Government Area of Anambra State. It is in Aguata zone which is one of the four Agricultural zones. Aguata zone comprised of Aguata, Orumba North, Orumba South, Nnewi North and Nnewi South Local Government Areas. Aguata (LGA) is made up of 14 towns which are divided into two major women groups, Aguata I and Aguata II. Each group has eight blocks in each different towns.

Aguata i has Ekwulobia, Igbo-Ukwu, Isuofia, Agulu-ezechukwu, Ezinifite, Umuona, Ora-eri and Ikenga. Aguata II women group consists of Umuchu, Akpo, Achina, Amesi, Uga and Nkpologwu. These groups of women are involved in crop farming, poultry farming, processing and palm kernel milling and cooperative societies. These blocks are being headed by females. Block Extension Agents (BEA), who visit them once or twice a month as the case may be. There are two female extension agents heading Aguata I and Aguata II women groups due to lack of female extension agents. The women group has 16 blocks in different towns with different names. At every meeting, representatives are being sent from each block to represent other women at the Local Government Headquarter, Ekwulobia. Many of the women farmer have not traveled beyond the LGA due to some logistical problems like having 
a reliable means of public transport. Secondly, getting the permission of their husbands to travel posed yet another obstacle.

One hundred and twenty (120) structured questionnaires were distributed with the assistance of the female block extension agents to the women groups. Ten (10) blocks were randomly selected from all the blocks. Twelve (12) women respondents were randomly selected from the block using simple random sampling so that women in each block would be represented. The variables sampled among others are years of farm experience, primary occupation of the women, sources of agricultural information, workshop/conferences attendance and rate/level of participation in agricultural decision-making. Data collected were expressed using descriptive statistics (frequently distribution tables) within which percentages responses and frequencies were calculated.

\section{RESULTS AND DISCUSSION}

Table 1 below shows that, 80 percent of the women farmers had between 10 to 20 years of farming experience which help them in making rational choice and decision to impact positively on the effective management and organization of their farms and families. However, 5 women farmers representing 4.2 percent has less than 5 years of farming experience because most of them are young, married, able-bodied women. Others are retired civil servants that engaged into farming few years ago and had 10 percent farming experience. The group of women farmers (about 5.8\%) had above twenty years farming experience and are aged.

\section{Years of Farming Experience}

TABLE 1: Distribution of respondents according to farming experience

\begin{tabular}{lcc}
\hline & Frequency & $\%$ \\
Less than 5 yrs & 5 & 4.2 \\
$5-9$ & 12 & 10.0 \\
$10-20$ & 96 & 89.0 \\
Above 20 Yrs & 7 & 5.8 \\
\hline
\end{tabular}

Table 2 below shows that majority of the women group (75.0\%) were full-time farmers that had contact with their block extension agents and also belonged to different cooperative groups. About 12.5 percent of the women engaged in petty trading. However, 8.3 and 4.2 percent of women engaged in processing/palm kernel cracking/shelling industry respectively. These groups diversify their sources of income and food more especially after daily work and on weekends. 


\section{Primary Occupation}

TABLE 2: distribution of respondents according to primary occupation

\begin{tabular}{|c|c|c|}
\hline & Frequency & $\%$ \\
\hline Farming & 90 & 75.0 \\
\hline Petty trading & 15 & 12.5 \\
\hline Processing/palm kernel cracking/shelling & 10 & 8.3 \\
\hline Civil service & 5 & 4.2 \\
\hline Total & 120 & 100.0 \\
\hline
\end{tabular}

Table 3 below displays the distribution of respondents according to their sources agricultural information. The most important source of agricultural information to the women farmers is through Agricultural agents $(75.0 \%)$ who usually are from the area of resident in the area and also keep the women abreast of new agricultural technologies. The second important source of agricultural information $(16.7 \%)$ is through the farmer multi-purpose co-operative societies. The result indicated that 3.3 percent of the respondents claimed they become aware of agricultural information though radio/television, though radio is always found in every household even in remote rural areas. About 4.2 percent of the women farmers become aware of the new technology through friends/neighbours/relations. About 0.8 percent of the women indicated they read about new technologies through bulletin and hand bills. This finding is in accordance with numerous studies which have shown that in co-operative farms, Extension Agents have remain the chief source of agricultural information to farmers (Patel and Ekpere, 1978).

\section{Source of Agricultural Information}

TABLE 3: Distribution of respondents according to sources of agricultural information

\begin{tabular}{|c|c|c|}
\hline & Frequency & $\%$ \\
\hline Friends/neighbours/Relations & 5 & 4.2 \\
\hline & 90 & 75.0 \\
\hline Agricultural & 20 & 16.7 \\
\hline & 4 & 3.3 \\
\hline $\begin{array}{l}\text { Co-operative Societies } \\
\text { Radio/Television }\end{array}$ & 1 & 0.8 \\
\hline New/Bulletin/Handbills & & \\
\hline Total & 120 & 100.0 \\
\hline
\end{tabular}

Table four below indicated that 60 percent of the women farmers were involved in crucial farm decision in their respective family levels as they supply most of the labour forces needed and maintain the running of their farm harvest. Twenty-five(25.0) percent of the respondents claimed that they had attended meetings and workshop at the local government council. Male farmers participated while their (women farmers) 
observed. The result indicated that 13.3 percent of the women farmers had attended agricultural extension conferences. Their presence were not felt. Only 1.7 percent of the respondents indicated they have participated in Agricultural group projects basically on their capacities.

\section{Level of Participation Agricultural Decision-Making}

TABLE 4: Distribution of respondents according to rate/level of participation in Agricultural Decision-making policies

\begin{tabular}{lcc}
\hline & Frequency & $\%$ \\
Family farm decisions & 72 & 60.0 \\
Agricultural extension meetings/workshop & 30 & 25.0 \\
Agricultural conferences & 16 & 13.3 \\
Agricultural group projects & 1 & 1.7 \\
$\quad$ Total & $\mathbf{1 2 0}$ & $\mathbf{1 0 0 . 0}$ \\
\hline
\end{tabular}

\section{CONCLUSION}

The study has indicated that women farmers in Aguata Local Government Area of Anambra State participate in major agricultural farming operations. These women also belong to different co-operative groups in their towns. Majority of them have longer years of farming experience which help them making effective decision at their family farm levels. However, they indicated that they do not participate in making major decisions, especially those that concern their welfare. In meetings where major decisions are taken, men did not consult them. It is hereby recommended that it should be a policy in the LGA to involve the women farmers in decision-making at all stages of group and family agricultural projects. Government should grant soft agricultural loans to women farmers to enhance their participation in agricultural decision-making and fund projects for achieving sustainable agricultural development. Women farmer's potentials can be more fully realized if they are integrated into the whole agricultural extension policy making decisions. In addition, government has to take into consideration other factors relates to the effectiveness of women farmers as participants to the high level forum. This would be an entirely new and potentially overwhelming situation for them, in which they would have to interact with powerful stakeholders such as ministers and senior government officials. Cultures that impede women farmers' participation in some socio-economic matters need to be reviewed to guarantee women equal participation in agricultural decision-making so that they will be at par with their main counterparts. 


\section{References}

Awake (1998) Cultural and Socio Values in "What Does the Future Holds for Women"? Pg 12-14.

Bakri, Z and Besha, R (1989) Women and Development in Eastern African; An Agenda for Research. Addis Ababa. OSSREA.

David K. (2006), Chair of the NAADS, Board of Directors, Uganda.

Davies, B and Ggraves, A.(1985) Ngambika, Studies of Women in Africa Literature, New Jersey: Africa World. Press Inc.

lloka, A.W. (2002) Communication Technique in Extension and Rural Development. Lecture note in Abia State University, Uturu, Umuahi Campus, Unpublished Manuscript.

Karunmi, O and Ezumah, A. (1989) Women's Role Cassava Production "In” Cassava based cropping system Research II. IITA Ibadan.

Mbilinyi, M. (1990) "A review of Women in Development Issues in Tanzania" A Paper prepared for the World Bank, Dar Es Salaam, Unpublished.

Okafor, C.N., Chukwu, G.O. and B.O (2002) The Role of Women in Food Production in Orumba North Local Government Area of Anambra State. In Food and Fibre Production in Nigeria in the $21^{\text {st }}$ Century. Proceedings of the First Annual Conference of the College of Agricultural and Veterinary Medicine, Abia State University, Umuahia. Pg 89-93.

Osula, Judith D.C. (1991) Enhancing Women's Economic Potential through Appropriate Technology in "Women in Nigeria Economy", ACENA Publishers, Enugu. Pg 70.

Patel, A and Ekpere, J.A (1987) Characteristics of Radio Listening Behaviour of farmers and Impact on Knowledge of Agricultural Innovations: Agricultural Administration Vol.5.

UNICEF (1985) Analysis of the Situation of Children and Women, Dar es Salaam.

UWT (1982) Taarifa Ya UWT:, Dar es Salaam, Voices. Rising. The ICAF Women's Programme. 